\title{
KEBIJAKAN KELAUTAN DALAM KERANGKA MENJAGA DAN MENGELOLA SUMBER DAYA ALAM LAUT
}

\author{
Nany Suryawati \\ Fakultas Hukum Universitas Katolik Darma Cendekia \\ Jl. Deles I No.29 Surabaya 60117 \\ Email: ra.nany@yahoo.com
}

\begin{abstract}
By not described the 1982 UNCLOS in detail yet on a legislation, give rise to conflicts of authority in the management of natural resources, particularly coastal and marine resources. With the enactment of Law No. 32 of 2004 on Regional Government, the central Government gives greater authority to local governments to be able to manage coastal and marine resources, as well as regulate the central and local financial balance from the proceeds of natural resource management in the region. With this expected welfare of the local community can be increased significantly. The amount of authority given to the local government not expected to pose an excessive sense of regionalism that could harm the unity of the Republic of Indonesia. Therefore we need a thought which is based on national interest and progress of the nation and the state, through law enforcement and legislation and specific policies in anticipation of a conflict of interest and the use of illegal conducted by both Indonesian citizens and foreign citizens, which may be detrimental to the Unitary Republic of Indonesia.
\end{abstract}

Keywords: Management, Utilization, Coastal and Marine Resources, Authority, Policy, Law Enforcement

\begin{abstract}
Abstrak
UNCLOS 1982 yang belum dijabarkan secara rinci dalam suatu peraturan perundangan-undangan, menimbulkan terjadinya konflik kewenangan dalam pengelolaan sumber daya alam, khususnya sumber daya pesisir dan laut. Dengan diberlakukannya Undang Undang Nomor 32 Tahun 2004 tentang Pemerintahan Daerah, Pemerintah pusat memberikan kewenangan yang lebih luas kepada pemerintah daerah untuk dapat mengelola sumber daya pesisir dan laut, sekaligus mengatur perimbangan keuangan pusat dan daerah yang berasal dari hasil pengelolaan sumber daya alam di daerah. Dengan ini diharapkan kesejahteraan masyarakat daerah setempat dapat meningkat secara signifikan. Besarnya kewenangan yang diberikan kepada pemerintah daerah tersebut diharapkan tidak menimbulkan rasa kedaerahan yang berlebihan sehingga dapat membahayakan kesatuan Negara Republik Indonesia. Oleh karena itu diperlukan suatu pemikiran yang berpijak pada kepentingan nasional dan kemajuan bangsa dan negara, melalui penegakkan hukum dan peraturan perundang-undangan dan kebijakan-kebijakan khusus dalam mengantisipasi terjadinya konflik kepentingan dan pemanfaatan secara illegal yang dilakukan baik oleh warga negara Indonesia maupun oleh warga negara asing, yang dapat merugikan Negara Kesatuan Republik Indonesia.
\end{abstract}

Kata Kunci: Pengelolaan, Pemanfaatan, Sumber Daya Pesisir dan Laut, Kewenangan, Kebijakan, Penegakkan Hukum. 


\section{A. Pendahuluan}

Negara Republik Indonesia sebagai suatu negara kepulauan yang besar dengan jumlah pulau kurang lebih 17.508, dengan garis pantai sepanjang $81.290 \mathrm{~km}$ dan luas lautan 5,8 juta $\mathrm{km}$, menimbulkan banyak permasalahan yang sangat kompleks dalam hal kebaharian, mulai dari garis batas, penangkapan ikan secara illegal, penambangan pasir illegal, terutama di wilayah ZEE, sampai dengan peraturan yang tertinggal dari perkembangan yang terjadi, bahkan terjadi tumpang tindih peraturan dalam menjaga dan mengelola sumber daya alam laut negara kita. Penjagaan wilayah laut Indonesia, belum dapat dilakukan dengan optimal, karena keterbatasan saran dan prasarana dari TNI Angkatan Laut kita. Di samping itu Konvensi Hukum Laut Internasional- UNCLOS 1982- masih belum ada peraturan yang menjabarkan ketentuan dari UNCLOS 1982 ini, sehingga diperlukan kerja sama dari setiap komponen yang ada di Indonesia, karena masih banyak komponen dalam masyarakat yang tidak peduli terhadap permasalahan yang terjadi di wilayah laut Indonesia yang berkaitan dengan penegakkan hukum di wilayah laut Indonesia. Adanya konflik kepentingan dan ketidaksinkronan antar sektor (pemerintah, masyarakat setempat dan swasta) ini, menyebabkan lemahnya penegakkan hukum di wilayah laut Indonesia. Di samping itu, konflik dalam hal kewenangan (jurisdictional conflict), untuk pengelolaan, pemanfaatan wilayah laut dan pesisir merupakan konfilk antar daerah, karena dampak yang muncul akibat kegiatan di daerah yang bersebelahan, ternyata belum dapat diantisipasi dengan baik. Hal ini menyebabkan pencemaran laut dan kerusakan ekosistem laut, terutama di daerah pesisir, dengan terjadinya deforestrasi mangrove, degradasi terumbu karang, yang menyebabkan berkurangnya keanekaragaman hayati laut, menjadi suatu permasalahan yang kompleks.

Kemiskinan masyarakat pesisir juga menjadi faktor yang memperberat permasalahan dalam pengelolaan dan pemanfaatan pesisir dan hasil lautnya, dengan subyek nya adalah masyarakat pesisir. Oleh karena itu, usaha - usaha untuk pengembangan, pengelolaan dan pemanfaatan serta pendayagunaan pesisir dan hasil lautnya, dalam rangka mempercepat peningkatan kesejahteraan masyarakat setempat, membutuhkan koordinasi antar instansi terkait, yang terkendala dengan birokrasi yang terkesan lambat dan tidak ada keterpaduan, padahal kerusakan ini harus segera diatasi dan diantisipasi supaya tidak bertambah luas. Kendala ini timbul dari adanya sikap yang lebih mengutamakan kepentingan sektoral dan kekakuan birokrasi, termasuk aspek perizinan baik untuk penelitian, survey dan pemetaan, maupun unttuk kepentingan dunia usaha, seringkali tidak mendukung. Aspek hukum dan perundang-undangan juga belum dapat mendukung karena lambatnya proses pembuatan suatu peraturan, sehingga terjadi ketidakpastian hukum yang mengakibatkan terjadinya konflik berkepanjangan yang menghambat usaha-usaha pembangunan di bidang perikanan dan sumber daya laut lainnya. Oleh karena itu, dengan adanya Undang Undang tentang Pemerintahan Daerah, menimbulkan tuntutan dari pemerintah daerah untuk diberi kewenangan dalam mengelola daerah pesisir dan hasil lautnya. Selama jaman orde baru, dengan dalih untuk kepentingan nasional, dilakukan eksploitasi terhadap kekayaan alam daerah termasuk kekayaan lautnya dan dinikmati pemerintah pusat tanpa memperhatikan masyarakat setempat, bahkan menimbulkan kesengsaraan dan penderitaan masyarakat yang 
berada di daerah tersebut. Tuntutan pemerintah daerah untuk diberi kewenangan mengelola sumber daya alam daerahnya, bertujuan untuk mensejahterakan masyarakat di daerah, dan juga untuk menerapkan perimbangan keuangan antara pusat dan daerah secara proporsional sesuai dengan prinsip-prinsip demokrasi, keadilan dan pemerataan. Hal ini tampak dalam Undang Undang No 22 tahun 1999 jo Undang Undang No 32 tahun 2004, tentang Pemerintahan Daerah, telah memberikan kewenangan pemerintah daerah (otonomi) yang lebih luas dalam mengelalola sumber daya alam daerah termasuk sumber daya pesisir dan lautan, mencakup kewenangan sampai 12 mil laut dari garis pantai pasang surut terendah untuk perairan dangkal dan 12 mil laut dari garis pangkal ke laut lepas untuk daerah provinsi dan sepertiga dari batas provinsi untuk daerah kabupaten.

Kewenangan daerah terhadap sumber daya pesisir dan lautan, meliputi kewenangan dalam : (a) eksplorasi, eksploitasi, konservasi dan pengelolaan kekayaan laut ; (b) pengaturan kepentingan administratif; (c) pengaturan tata ruang; (d) penegakan hukum terhadap peraturan yang dikeluarkan pemerintah daerah atau yang dilimpahkan kewenangannya oleh pemerintah; dan (e) bantuan penegakkan keamanan dan kedaulatan negara, khususnya di laut. Akan tetapi kewenangan yang diberikan kepada daerah ini diharapkan tidak menimbulkan rasa kedaerahan yang berlebihan yang membahayakan Negara Kesatuan Republik Indonesia. Di samping itu, sungai-sungai yang bermuara di laut memiliki potensi sebagai saluran bagi bahan pencemar dari laut, oleh karena itu, untuk mencegah masuknya bahan pencemar dari laut ini, melalui upaya berupa peningkatan kualitas air sungai terlebih dahulu. Pemerintah telah merevisi Peraturan Pemerintah (PP) Nomor 20 Tahun 1990 dengan Peraturan Pemerintah Nomor 82 Tahun 2001, tentang Pengelolaan Kualitas Air dan Pengendalian Pencemaran Air; upaya pemerintah ini antara lain : menetapkan daya tampung beban pencemaran, menginventarisasi sumber pencemar dan memantau kualitas air. Upaya ini diawali dari pemantauan terhadap industri-industri yang menghasilkan sisa produksi yang akan dibuang baik ke sungai maupun ke laut, wajib memenuhi kriteria baku mutu air limbah yang telah ditetapkan pemerintah. Baku mutu air limbah dari kegiatan industri, kegiatan hotel, kegiatan rumah sakit, kegiatan pengeboran minyak dan gas serta panas bumi, kawasan industri, dan pertambangan batu bara. Pemantauan kualitas air ini seharusnya diserrtai dengan penerapan hukum dan peraturan yang memihak pada kepentingan nasional. Oleh karena itu ketentuan-ketentuan UNCLOS 1982 yang meliputi:

Laut territorial yang tidak melebihi 12 mil laut diukur dari garis pangkal normal; zona tambahan bagi negara pantai untuk melakukan pengawasan; zona ekonomi eksklusif yang merupakan wilayah di luar dan berdampingan dengan laut territorial yang tidak melebihi jarak 200 mil laut; landas kontinen suatu negara yang meliputi dasar laut dan tanah dibawahnya dab daerah permukaan laut yang terletak diluar laut teritorialnya; laut lepas yang tidak termasuk zona ekonomi eksklusif; aturan pulau yang terbentuk secara alamiah; laut tertutup dan setengah tertutup adalah laut yang dikelilingi oleh dua atau lebih negara dan dihubungkan dengan laut lain atau samudera atau alur yang sempit; selat yang digunakan untuk pelayaran internasional, aturan akses negara tidak berpantai ke dan dari laut serta kebebasan transit yang ditetapkan dengan suatu perjanjian; kawasan dasar laut internasional yang berkaitan dengan penambangan sumber daya alam di dasar laut; dan perlindungan serta pelestrarian lingkungan laut untuk pencegahan pencemaran laut;riset 
alamiah pengembangan dan alih teknologi kelautan, penyelesaian sengketadan ketengtuan penutup. ${ }^{1}$

Dalam Pardo Resolution (Desember 1970) menetapkan : dasar laut dan dasar samudera, dan tanah dibawahnya di laur batas yurisdiksi nasional, serta sumber-sumber kekayaan alam di area, adalah warisan bersama umat manusia. ${ }^{2}$

Berdasarkan prinsip "Common Heritage of Mankind" dalam pengatauran 'area', yaitu : dasar laut dan dasar samudera serta tanah dibawahnya di luar batas yurisdiksi nasional, ${ }^{3}$ yang kaya akan mineral dan kekayaan ini harus dimanfaatkan untuk kepentingan pemerataan keuntungan dan kesejahteraan manusia, maka dimanfaatkan secara bersama-sama.

\section{B. Pembahasan}

Penerapan hasil UNCLOS 1982 di Indonesia melalui Undang Undang Nomor 17 tahun 1985 yang mengatur tentang pertambahan luas wilayah nasional; zona ekonomi eksklusif yang meliputi kedaulatan atau kewenangan dalam mengelola sumber daya laut dengan cara eksplorasi, eksploitasi, dan konservasi di daerah pesisir pantai dan laut, hanya saja tetap harus diperhatikan untuk alih teknologi kelautan (khususnya untuk penambangan dasar laut dan samudera) dalam rangka mensejahterakan masyarakat setempat. Alih teknolagi merupakan suatu proses jangka panjang, adalah konsep penyampaian suatu ilmu dari satu generasi ke generasi berikutnya.

Seluruh wilayah laut tersebut harus dikelola dan dimanfaatkan sebaik-baiknya dan secara berkelanjutan. Pengelolaan dan pemanfaatan sumberdaya kelautan, meliputi: mengenal berbagai jenis laut Indonesia, mengenal berbagai sumber daya alam baik yang berada di dalam wilayah perairan maupun yang berada diluar wilayah perairan, mampu mempertahankan kedaulatan wilayah negara RI, menerapkan kewenangan dan penegakkan hukum serta kebijakan kelautan dalam rangka mengantisipasi terjadinya konflik kepentingan, dengan tetap menghormati hak-hak internasional, mengatasi pencurian ikan (illegal fishing), serta mampu memelihara lingkungan laut dan memanfaatkan sumber daya nya secara sustainable, dan terutama mampu menjaga kedaulatan wilayah negara RI, dan juga mampu memnafaatkan sumber daya laut yang berada di laut lepas dan di dasar laut internasional, sehingga membutuhkan suatu peraturan baru yang mengatu tata ruang eklautan, yaitu ; Undang Undang Nomor 27 tahun 2007 jo Undang Undang Nomor 1 tahun 2014 - tentang Pengelolaan Wilayah Pesisir dan Pulau-Pulau Kecil. Adanya Undang Undang Kelautan dan kebijakan nasional sangat dibutuhkan untuk menegakkan hukum di wilayah laut negara RI, agar pengelolaan laut menjadi terintegrasi.

\footnotetext{
T. May Rudy, Hukum Internasional 2, 2009, Refika Aditama, Bandung, h. 18-20.

Badan Pembinaan Hukum Nasional Departemen Kehakiman, Himpunan Karya Tulis Bidang Hukum, 1991, Departemen Kehakiman RI, h. 159.

Ibid
} 
Menteri Kelautan dan Perikanan RI - Susi Pudjiastuti telah mengeluarkan berbagai kebijakan yang terkait dengan pengelolaan sumber daya laut pesisir dan sumber daya laut serta pengamanan wilayah perairan Negara RI daro pencurian ikan (illegal fishing) dengan penenggelaman kapal illegal tereebut, dan berbagai kegiatan yang dilarang (misalnya : larangan alih muatan di tengah laut), karena Menteri berpendapat bahwa kekayaan laut Negara RI sangat besar, tetapi selama ini hanya dinikmati oleh negara lain. Selain mengeluarkan berbagai kebijakan, Kementerian Kelautan dan Perikanan (KPP) meklakukan jaringan kemitraan dengan lembaga non negara, seperti: media massa, organisasi kemasyarakatan di daerah pesisir, dan tokoh-tokoh non negara lainnya. Keterlibatan tokohtokoh non negara ini akan sangat membantu upaya Kementerian Kelautan dan Perikanan dalam mengantisipasi berbagai penyelewengan dan pelanggaran yang terjadi di wilayah laut Negara RI.

Pasal 3 Undang Undang Nomor 43 Tahun 2008 tentang batas Wilayah, menentukan bahwa: Pengaturan wilayah bertujuan untuk :

1. Menjamin keutuhan wilayah Negara, kedaulatan Negara dna ketertiban di Kawasan Perbatasan demi kepentingan kesejahteraan segenap bangsa;

2. Menegakkan kedaulatan dan hak-hak berdaulat; dsn

3. Mengatur pengelolaan dan pemanfaatn wilayah Negara dan kawasan perbatasan, termasuk pengawasan batas-batasnya.

Pasal ini merupakan perwujudan dari Pasal 25 A UUD NRI 1945, yang menentukan ; Negara Kesatuan RI adalah sebuah negara kepulauan yang berciri Nusantara dengan wilayah yang batas-batas dan hak-hak nya ditetapkan dengan undang undang.

Ketentuan dalam Pasal 1 angka 4,5 dan 10 Undang Undang Nomor 43 Tahun 2008, memuat beberapa hal yang penting untuk diperhatikan yaitu :

1. kedaulatan atas wilayah serta memiliki hak-hak berdaulat di luar wilayah kedaulatannya untuk dikelolaaa dan dimanfaatkan sebesar-besarnya bagi kemakmuran rakyat Indonesia;

2. Sisi terluar dari wilayah negara atau kawasan perbatasan, merupakan kawasan yang strategis dalam menjaga integritas serta keutuhan wilayah Negara RI

3. Kepastian hukum mengenai area wilayah negara, kewenangan pengelolaan wilayah negara yang terkait dengan hak suatu Negara yng berdaulat.

Menurut Oppenheim, tanpa adanya batas-batas tertentu bagi suatu wilayah negara, maka negara yang bersangkutan tidak dapat dianggap sebagai subyek hukum internasional. ${ }^{4}$

Membahas tentang negara tidak akan pernah terpisahkan dari konsep kesatuan geografis, beserta kedaulatan dan yurusidiksi wilayahnya. Hal ini menyebabkan wilayah suatu negara menjadi dasar untuk pemberlakukan kedaulatan sebagai kekuasaan tertinggi suatu negara berdasarkan batas-batas wilayah yang dimilikinya. UNCLOS 1982 sebagai suatu konvensi

4 Oppenheim, International Law, Vol 8 , 1955, h. 451. 
internasional yang mengatur semua ketentuan penting termasuk kegiatan yang dilakukan di laut beserta aspek-aspeknya.

Ketentuan dalam Pasal 6 ayat (2) Undang Undang Nomor 43 Tahun 2008, menetapkan bahwa batas wuilayah negara sebagaimana dimaksud dalam ayat (1), termasuk titik koordinatnya ditetapkan berdasarkan perjanjian bilateral dan/atau trilateral, terkait dengan penjelasan Pasal 6 ayat (3) yang menjelaskan bahwa : penetapan batas wilayah negara dilakukan melalui perjanjian bilateral dan/atau trilateral apabila terdapat dua atau tuga negara yang menyatakan pengakuan atas wilayah yang sama ataupun adanya kemungkinan tumpang tindah pengakuan atas wilayah yang sama. Penetapan batas wilayah negara dilakukan secara unilateral apabila tidak terdapat pengakuan atas wilayah yang sama ataupun tidak adanya kemungkinan tumpang tindah pengakuan atas wilayah yang sama; dengan demikian maka batas wilayah merupakan " a defined territory”, dan Negara RI memiliki perbatasan laut dengan 10 (sepuluh) negara yaitu : Australia, Filipina, India, Malaysia, Palau, Papua Ngini, Singapura, Thailand, Timor Leste dan Vietnam, serta 3 (tiga) wilayah darat dengan negara Malyaisa, Papua Nugini dan Timor Leste. Mencermati banyaknya negara yang berbatasan dengan Negara RI, maka permasalahan perbatasan dan penerapan kedaulatan Negara RI merupakan suatu prinsip mutlak yang tidak dapat dinegosiasikan (non negotiable), dan akan selalu menjadi konflik territorial yang serius bagi perdamaian dan keamanan internasional. Untuk itu, Kementerian Kelautan dan Perikanan (KPP) berupaya keras menegakkan hukum di wilayah Negara RI dengan mengatasi permasalahan yang terjadi, melalui suatu sikap tegas dan non kompromi. KPP telah berkoordinasi dengan berbagai Kementerian khususnya Kementerian Luar Negeri, Kementerian Perhubungan, Kementerian Perdagangan, Kementerian Perindustrian serta Tentara Nasional Indonesia (TNI) sehingga diharapkan antisipasi kegiatan illegal di wilayah pesisir laut dan laut dapat teratasi.

KKP dengan dibantu TNI telah melakukan tindakan tegas terhadap kapal-kapal ilegal yang berhasil ditangkap di perairan Indonesia. Penenggelaman kapal yang dilakukan oleh KKP dibantu TNI memiliki dasar dan kekuatan hukum yaitu : Pasal 69 Undang Undang Nomor 45 Tahun 2009 tentang Perubahan atas Undang-Undang Nomor 31 Tahun 2004 tentang Perikanan, yang menetapkan bahwa pengawas perikanan dapat melakukan tindakan khusus berupa pembakaran dan/atau penenggelaman kapal perikanan yang berbendera asing berdasarkan bukti permulaan yang cukup. Selain penenggelaman kapal tersebut, pemrintah RI melalui Kementerian Luar Negerri meminta kepada negara tetangga agra mengawasi nelayan untuk tidak masuk wilayah Negara RI secara illegal serta melakukan illegal fishing dilwilayah perairan Negara RI. Diplomasi maritime juga dilakukan oleh Kementerian Kelautan dan Perikanan (KPP) untuk mendukung efektivitas kebijakan dari KPP, demikian dengan Kementerian Perindustrian dan Kementerian Perdagangan, dengan mempersiapkan industri sumber daya laut di berbagai pesisir pantai di wilayah Negara RI. Sedangkan koordinasi dengan Kementerian Luar Negeri dilakukan untuk masalah bea hasil laut dan pasar yang potensial di luar negeri untuk pendistribusian hasil laut Indonesia. Kementerian Perhubungan mendukung dengan kemudahan serta biaya yang ekonomis dan efisien untuk pengiriman hasil laut ini keluar negeri melalui lintas udara dan lintas laut. Pengawasan yang efektif dan 
penegakkan hukum secara tegas di wilayah perairan negara Indonesia, khususnya terhadap kegiatan illegal fishing, menyebabkan hasil laut Indonesia di pasar dunia akan mengalami penurunan, sehingga kesiapan kerja sama yang sinergi dan harmonis antar kementerian ini sangat diperlukan. Pengelolaan hasil laut secara terpadu ini merupakan suatu proses yang berkesinambungan, interaktif, adaptif dan partisipatif. Dibutuhkan peran serta dari semua elemen dan setiap lembaga untuk melaksanakan fungsinya masing-masing secara optimal sehingga cita-cita membangun Indonesia sebagai poros maritim dapat terwujud.

Negara Kesatuan Republik Indonesia yang diakui secara internasional sebagai suatu negara kepulauan memiliki sumber daya alam yang melimpah dan wilayah laut Indonesia merupakan bagian terbesar dan memiliki posisi dan nilai strategis dari berbagai aspek kehidupan yang emliputi aspek politik, ekonomi, sosial budaya, pertahanan dan keamanan serta ekologi, yang keseluruhan aspek ini merupakan modal dasar untuk terwujudnya kesejahteraan dan kemakmuran masyarakat khususnya masyarakat pesisir. Sedangkan upaya pengamanan wilayah keadulatan yang berkaitan dnegan yurisdiksi dan asset Negara Kesatuan RI, meliputi : pengembangan sistem monitoring,control and survaillance (MCS), sebagai instrument pengamanan sumber daya, lingkungan dan wilayah kelautan serta wilayah perbatasan dan pulau-pulau kecil terdepan/terluar, dan penanganan pelanggaran yang terjadi di laut. Di samping itu kebijakan lain yang dipeelukan untuk menunjang pelaksanaan tersebut diatas, adalah : mempersiapkan sumber daya manusia yang berkualitas dalam hal kelautan dengan seluruh permasalahannya melalui pelatihan-pelatihan untuk meningkatkan kompetensi sumber daya manusia di bidang kelautan dan mendorong peran ilmu pengetahuan dan teknologi serta penelitian untuk pengembangan pemanfaatan sumber daya laut dan juga pengembangan sistem informasi kelautan.

Negara Kesatuan RI adalah negara kepulauan (archiepelago state), yang berbentuk kesatuan dan berwawasan Nusantara, harus segera memiliki paradigma baru bagi Indonesia baru yang lebih berorientasi pada visi pembangunan kelautan di segala bidang. Untuk mewujudkan hal ini, diperlukan peraturan perundang-undangan sektoral di bidang kelautan , baik yang telah ada maupun yang masih berbentuk rancangan undang-undang, memerlukan kebijakan peneglolaan yang menyeluruh dan terpadu. Adapun RUU tersebut, seharusnya memuat substansi yang mengacu pada : (a) penegasan kedaulatan; (b) pengelolaan ruang laut; (c) pengelolaan sumber daya laut; (d) fungsi dan koordinasi antar lembaga. Kesiapan dari KPP dibawah komando Menteri Susi diharapkan dapat di teruskan secara berkesinambungan dan senantiasa di evaluasi demi mengantisipasi perkembangan di semua aspek yang berkaitan dengan kelautan.

\section{Penutup}

Jika kita perhatikan berbagai permasalahan yang timbul dalam pemanfaatan dan pengelolaan daerah pesisir laut, antara lain : 
1. Pemanfaatan dan pengelolaan daerah belum diatur dengan peraturan perundangundangan yang jelas, seingga daerah mengalami kesulitan dalam menetapkan suatu kebijakan, khususnya yang terkait dengan wilayah perbatasan negara;

2. Pemanfaatan dan pengelolaan daerah pesisir cendrung bersifat sektoral, karena lebih mendahulukan kepentingan sector;

3. Pemanfatan dan pengelolaan daerah pesisir belum memperhatikan konsep daerah pesisir sebagai suatu kesatuan ekosistem yang tidak dibatasi oleh wilayah administratif pemerintahan, sehingga menimbulkan konflik antar daerah;

4. Kewenangan daerah (otonomi daerah) belum dipahami secara komprehensif oleh para stakeholders, menimbulkan pemahaman yang berbeda-beda

Mencermati kompleksnya permasalahan yang terjadi di bidang kelautan, maka yang perlu dilakukan adalah melaksanakan kesepakatan UNCLOS 1982 yaitu : mempertegas batas wilayah laut Negara Indonesia, mendata umber daya kelautan, menjalin hubungan internasional dan melaksanakan hak serta kewajiban dalam mengelola sumber daya kelautan. Di samping itu mensosialisasikan pendidikan dan penyadaran masyarakat tentang kelautan khususnya bagi masyarakat pesisir, sekaligus merevitalisasi masyarakat hukum adat dan kearifan local di bidang kelautan, sehingga wawasan Nusantara dan wawasan bahari benarbenar dipahami. Sedangkan upaya merubah paradigma di bidang kelautan, perlu adanya pembanguna sistem hukum dan tata pemerintahan, pengembangan sistem koordinasi, perencanaan, monitoring dan evaluasi yang berkesinambungan. Pemantapan ekonomi kelautan melalui kegiatan yang menguntungkan antar lain : percepatan pembangunan industri kelautan, perikanan, energi dan sumber daya mineral, wisata bahari dan jasa kelautan, serta bioteknologi dan biofarmakologi kelautan, sebagai sarana untuk meningkatkan kesejahteraan masyarakat Indonesia, khususnya masyarakat di tempat sumber daya alam itu berada. Adapaun RUU Kelautan diharapkan menetapkan ketentuan-ketentuan yang menjadi dasar bagi percepatan pembangunan di bidang kelautan dan perikanan.

Penekanan terhadap wawasan Nusantara dan wawasan bahari menjadi dasar dari keseluruhan kegiatan di bidang kelautan dan perikanan. Tugas akbar dari Kementerian kelautan dan Perikanan beserta Kemanterian-kementerian lainnya yang terkait.

\section{Daftar Pustaka}

Badan Pembinaan Hukum Nasional Departemen Kehakiman, Himpunan Karya Tulis Bidang Hukum,1991, Departemen Kehakiman RI, Jakarta

Oppenheim, International Law - Vol 8, 1955

Rudy, T, May, Hukum Internasional 2, Refika Aditama, Bandung, 2002

\section{Perundang-undangan}

Undang Undang Dasar Negara Republik Indonesia Tahun 1945. 
Undang Undang Nomor 32 Tahun 2004 tentang Pemerintahan Daerah

Undang Undang Nomor 43 Tahun 2008 tentang Wilayah Negara

\section{Makalah}

Haryono, P. Harry, Negosiasi Perjanjian Internasional Tentang Kewilayahan, Seminar Nasional "Implementasi Perjanjian Internasional Tentang Batas Wilayah Suatu Negara", 2009, Surabaya.

Tirtamulia, Tjondro, Batas Kedaulatan Wilayah Negara Kepulauan, Seminar Nasional "Implementasi Perjanjian Internasional Tentang Batas Wilayah Suatu Negara “, 2009, Surabaya. 